\title{
CHANGES IN COASTAL SEDIMENTARY ENVIRONMENTS AND REMOTE SENSING DATA IN FRENCH GUIANA
}

M.T.Prost ${ }^{1}$

\section{ABSTRACT}

Present-day morphological shoreline changes in French Guiana are very dynamic, striking and specific, directly linked to the huge Amazon discharge. One part of this supply moves in suspension offshore: the other part (some 110 million $\mathrm{m}^{3} /$ year) moves in the form of vast migrating shoreface-attached mudbanks, separated one from the other by erosional interbank zones. On account of this dynamics, shoreline is continually changing and a specific sedimentation pattern (with alternating deposition and erosion sectors) characterizes the coastal area. Remote Sensing Data processing (LANDSAT MSS and SPOT) is being widely used (ORSTOM-Cayenne) as an essencial research strategy and methodology that also helps to an approach of some significant questions on coastal palaeoenvironments.

\section{INTRODUCTION}

A specific sedimentation pattern with alternating sectors of deposition (muds) and erosion (sands) characterizes the foreshore/shoreface area along the $320 \mathrm{~km}$ of the French Guiana coast, namely:

(a) Wide shoreface-attached mudbanks, $40 / 60 \mathrm{~km}$ long, that migrate slowly to the NW through the action of the current and swell. When a bank is linked to a sector of the coast this one is under progradation.

\footnotetext{
Centre ORSTOM, Cayenne, French Guiana.
} 
(b) Erosional interbank zones (with similar size) where sand cheniers are formed. Owing to the increase of the erosion the shoreline retreats, even if formed by a mangrove forest. In some cases, subcoastal swamps and marshes become connected with the open sea.

At present there are six mudbanks along the coast, two situated east of Cayenne and the others migrating between Cayenne and the Maroni River. Westward-migrating average rate of mudbanks (and interbank zones) is approximately $1 \mathrm{~km} /$ year. Periodicity of the deposition/erosion cycle appears to be on the order of 30 years (DIRECTION DÉPART. DE I'EQUIPEMENT, 1988).

Our poster focused on modern changes on these coastal sedimentation environments which are investigated with the help of advanced technology on Remote Sensing data. This one also leads to an approach of some significant questions on Holocene sedimentary changes on the coastal plain and the inner shelf area.

\section{MODERN COASTAL SEDIMENTATION PATTERN}

\section{Mudshoals, mudflats and Remote Sensing Data}

The inner shelf of French Guiana presents a transition from nearshore muds to offshore sands: a Holocene "mud blanket" (clays and silt clays with less of $5 \%$ of fine-sand) covers the shelf until $20 / 25 \mathrm{~km}$ from the strandline and to the 25-30 m deep contour; beyond this point stretches a relict Late Pleistocene sandy surface (BOUYSSE et al., 1977; JEANTET, 1982; PUJOS \& ODIN, 1986 and PUJOS \& BOUYSSE, 1988).

Owing to acoustical surveys done in Suriname and Guiana (DELF HYD. LAB, 1962; DIEPHUIS, 1966; NEDECO, 1968; AUERSMA, 1968; AUGUSTINUS, 1978, etc.) the topography of the seabottom representative for the whole Guiana coast was defined south of the $20 \mathrm{~m}$ isobath; wavy contour pattern is caused by the alternation of giant mudwaves (mudshoals) - extending obliquely from the coast into the sea - and intermediate troughs. The average "wavelength" is approximately 45 km (AUGUSTINUS, 1978).

Palaeogeographical, sedimentological, hydrological and oceanographic data prove that the Amazon River and its dispersal system are the prevailing source of the coastal muds. The Andes and the SW Amazon lowlands are the main areas supplying sediments (FRANZINELU, 1988 and KROOK, 1988), 10 to $20 \%$ of the immense amazonian output (11-13 $\times 10^{8}$ tons $\mathrm{yr}^{-1}$ of suspended matter) is moving along the Guiana coast (EISMA, 1988), one part offshore (transported by the Guiana Current), the other part as migrating shoreface-attached mudbanks. The part of the French Guiana rivers to the coastal sedimentation is extremely weak (<1\%, LOINTIER \& PROST, 1988). 
The HRV1 SPOT view (689 339, 20th October 1986 mode XS, bands 1, 2 and 3, pixel = $20 \mathrm{~m}$; Local Time = 12:10; tide conditions = LWL at the Islands of Salut) shows the marine environment of the Sinnamary area (situated at about $120 \mathrm{~km} \mathrm{~W}$ of Cayenne). Oblique aim of SPOT $\left(26^{\circ}\right.$ ) gives information concerning wave action and swell diffraction in the shoreface and suggests the pattern and the seaward extension of the offshore mudshoals (LOINTIER \& PROST, 1988).

During the past $\mathbf{3 0}$ years, but particularly since the mid-seventies, many publications lay stress on the rapidity of morphological variations of the French Guiana coast through the migrating mudbanks (TURENNE, 1978; FROIDEFOND \& PROST, 1985; FROIDEFOND ot al., 1985; PROST, 1986, 1987, 1988; FROINDEFOND \& PUJOS, 1988; LOINTIER \& PROST, 1988; DIRECTION DEPARTAMENTALE DE L'EQUIPEMENT, 1988 and PROST et al., 1989). Coastal variations were analysed owing to vertical aerial photographs, flights survey, field evidence and the comparison of historical maps.

At present it is possible to do accurate mapping of mudflats of through the SPOT views (October 1986, spatial resolution of $20 \mathrm{~m}$ ) taken one hour before mean low spring water level: under these conditions, coastal muds are easily identified owing to their homogeneous reflectance. The technique of isocontours (lines of equal reflectance) was used by M.Lointier to define mudflats limits (band 1) and to calculate exactly their surface. It was done as follows: Cayenne mudflat, 15,9 km; Kourou-Sinnamary mudflat, $65,9 \mathrm{~km}^{2}$ and Iracoubo mudflat, $28,6 \mathrm{~km}^{2}$. Then, the total surface covered by mudflats between Cayenne and Iracoubo (132 km of shoreline) is $110,4 \mathrm{~km}^{2}$.

Of course, as the shoreline is very unstable, the probability of these dimensions being preserved for many years is very low. For a better recognition of these subenvironments another approach is necessary, the superposition and comparison of the LANDSAT MSS (October 1976) and SPOT (October 1986) views. They give exact information on major morphological changes (accretion/erosion) in some areas on 10 years time-scale.

- On the one hand, a significant coastal erosion takes place (1) along the whole shoreline between Cayenne and Kourou and (2) in the Sinnamary area where the strandline retreats inland $2 \mathrm{~km}$ and the estuary $4 \mathrm{~km}$ inland;

- on the other hand, (1) muds accumulation originates a $2 \mathrm{~km}$ progradation on the Kourou-Malmanoury coast (2) and a $14,0 \mathrm{~km}^{2}$ gain on the Iracoubo mudflat,

- and finally, the Cayenne shoreline is almost free of muds in 1976; in October 1986, on the contrary, SPOT view reveals a 15,9 $\mathrm{km}^{2}$ mudflats behind which sandy beaches are fixed. At present, sandy accretion takes place again, except on the east part neighbouring the Cayenne River mouth - where the mudflats still remains. 
Sand accumulates within the estuarine environment and on the foreshore portion of the interbank zones that is erosional in character. Beach profiles vary quickly within months or weeks.

The Cayenne coast, between the Mahury and the Cayenne Rivers, is one of the rare points of the shoreline where the rocks of the shield are in contact with the ocean. As a result, the coastline is a succession of rocky points and isolated hills separating sand coves and straight beaches. Sands appear to be of local sources, transported by the rivers and reworked by the sea. They are mostly coarse-grained composed of almost pure quartz and present a good sorting. Grains morphoscopy reveals a double supply (and a complex evolution) with one part of bright grains (from local immature source) and another significant part formed by coloured ochre quartz grains. These grains have a corroded and ragged surface where deep holes are filled with darkredbrown coating, resulting of weathering. Shell clastics are rare and appear only near some rocky points. Concentration of heavy minerals is found within the high foreshore area and is linked with swash-backwash process.

The processing of the HRV1 SPOT view (October 1986) shows beach ridges trapped behind mudflat; bare sand appears very cleary thanks to its excellent reflectance. Afterwards, the mudflat migrates to the west and sandy beaches are now replenished within the interbank zone. Along the straightcoasts, for instance, sands progresse and accumulate over the muds by a longshore drift; beaches profiles change completely in several months time-scale. They are still changing, and strong erosion points (with a backshore retreating and a ridge and funnel foreshore topography) exist nowadys in the west part of these straight-coasts.

However the most striking example of erosional siliciclastic shoreline French Guiana is presently the area of the Marais Sarcelle and the Pointe Isère, near the Maroni River. Flight over reveals a typical erosional wave-dominated shoreline with washover-type beaches and straight sandy coast. A sharply indented coast (happen-coast) stretches near the Maroni estuary (Pointe Isère) indicating sparse sand and a strong erosion.

\section{EVIDENCE OF PAST SEDIMENTARY CHANGES}

The Holocene coastal plain, roughly situated between 0 and $5 \mathrm{~m}$ high and with 5 to 30 $\mathrm{km}$ in width, is an open ocean chenier plain. Cheniers are located among swamps and marshes covering the Demerara muds, both well defined on the satellite views.

The Holocene fine-grained depositional phases

Three phases of fine-grained sedimentation were recognized within the Demerara 
Formation (BOYE, 1959; LEVEQUE, 1962; TURENNE, 1978, etc), namely:

- Mara, the oldest $(8,000 / 6,000 \mathrm{BP})$,

- Moleson (2,600/1,300 BP),

- Comowine (1,000 BP to the present).

The Mara sediments - that occur in large areas in Suriname and in Guiana cover only a small area in French Guiana, especially at the west coast (zone of Mana Iracompany). The deposits are mainly formed by soft, grey, unmottled to hardly mottled clays and by peaty clays, with sand layers and high pyrite contents.

The depositional conditions of these sediments are related to sea-level rise. In fact, evidence from palynological analysis, foraminifera and ${ }^{14} \mathrm{C}$ dating of a $22,40 \mathrm{~m}$ deep core taken from the Marais Sarcelle (GUY-2, west French Guiana coast) by TISSOT et al. (1987) shows:

(a) from ca. 9,000 to ca. 5,000 years B.P. (from the base of the core up to $8 \mathrm{~m}$ ) the sea level rising (Holocene transgression);

(b) a dominance of Rhizophora polen in the palynological assemblages indicating that the site is located within the mangrove forest.

These results are in accordance with those obtained in Guiana and Suriname (VAN DER HAMMEN, 1963; WIJMSTRA, 1971; WONG, 1986, etc); 19 radiocarbon data from Mara deposits (ROELEVELD \& VAN LOON, 1978) fits into the picture of a rapid sea-level rise until about 6,000 B.P.

A drastic change appeared in the palynological diagram at ca. 5,000 B.P., it indicates the mangrove forest being replaced by a swampy savanna. Authors uphold this stage is the result of a stabilization of the relative sea-level (the local net rate of sedimentation being comparable to the rate of the sea-level rise) "which permits a progradation of the sediments and a seaward shifting of the shoreline".

That means a stable sea-level during the accumulation of the Moleson sediments. During a borehole survey across the swamps and marshes of the Mana area we noticed that the greyishblue clay of Moleson superficially desalinized and covered by a peat layer $(50 / 60 \mathrm{~cm}$ thick) was brown and yellow mottled and generally half ripned. These clays correspond partially to the site of brackish marshes located above the highest spring tide level.

The Comowine deposits appeared in the upper part of the palynological diagram of the Marais Sarcelle in connection with the expansion of the Avicennia forest. Present-day sediments are composed by salted light-grey clays, nearly ripned to unripned, covered by the normal tides and by the mangrove forest.

The brackish and fresh water swamps and marshes developed on the Mara and Moleson sediments, as well as the waterfront mangrove located on the Comowine deposits, are being analysed through the SPOT data. The aim is a thematic mapping of the subcoastal environments. A cross section was then processed (as a first approach) within the mangrove forest of the Iracoubo area (LOINTIER \& 
PROST, 1988). Owing to the information obtained from the bands 1,2 and moreover from the band 3 , several radiometric histograms have been done pointing to the different types of mangrove (pionner, young, adult, decaying, dead) very likely associated to local shoreline fluctuations. Two other processing were associated to the histograms in order to supply further information: the Vegetation Index: IV $=\left(c^{3}\right.$. $\left.c^{2}\right) /\left(c^{3}+c^{2}\right)$ and the Brightness Index: IB $=\sqrt{(\mathrm{C} 1)^{2}+(\mathrm{C} 2)^{2}}$.

\section{The associated chenier's system}

The chenier plain of French Guiana is a multi-membered, progradational ridge-interridge mudflat sequence. Aerial photographs, low altitude flights, satellite views processing and field observations enabled us to identify narrow cheniers along the shoreline and in the inner part of the "young" coastal plain, SPOT views reveal these sand bodies disposed as isolated ridges in extensive swamps and marshes areas, roughly parallel to the coast. At margins of estuaries, however, cheniers may present an upstream deflection.

Information on the physical environment of cheniers includes detailed studies on sedimentary structures (AUGUSTINUS, 1978) grain size parameters and mineralogy (KROOK, 1979, and PROST, 1988, in press.). Cheniers between Cayenne and the Maroni are essentially built up of medium to coarse sand (whereas in Suriname and Guiana they are also made of fine sand and shell fragments). Borehole surveys done at the Mana and Sinnamary areas (PROST, in press.) reveal that cheniers sands with 1-2 $\mathrm{m}$ depth - transitionally overlie silty clays and clays, forming an upwards coarsening sequence. Shells are scarcely found within these sands, except in few areas.

That coarse material originates from local sources is obvious (PROST \& LOINTIER, 1988 and JOUANNEAU \& PUJOS, 1988). The problem which must be considered is the origin of the fine sand physically, fine sand from the Amazon River may travel with the mud (AUGUSTINUS, 1978 and KROOK, 1979) and could be winnowed by hydrodynamic processes. However fine Amazon borne sand has not been found in French Guiana so far.

\section{PROGRADING AND RETROGRADING SEQUENCES AND THEIR PERIODICITY}

It is quite possible that a view of the coastal landscape gives the wrong impression of sharp contacts between prograding and retrograding sequences. Or as RINE \& GINSBURG (1985) have shown, mud and sand enviromenments of shoreface- foreshore areas pass gradually from one into the other. In fact stacking of sediments from migrating mudbanks creates on the shoreface a vertical sequence of laminated and massive muds with discontinuity features and on the coastal plain a horizontal sequence 
of mud marshes and sand cheniers.

Migration of the shoreline in a landward or in a seaward direction depends upon various factors that can be grouped into two parameters (READING, 1986): rate of deposition and rate and direction of relative sea level change. The shoreface mud blanket and the accumulation on the coastal plain of the Mara sediments are linked to the Holocene transgression. However, the interpretation of the post - Mara coastal evolution remains questionable. Lateral accretion alternating with phases of erosion "became predominant" (ROELEVELD \& VAN LOON, 1978). RINE (1980) upholds that migration of mudbanks is probably a process that has occurred annualy for the last 3,500 years "but variations" in vertical distances between discontinuity features and in horizontal distances between cheniers indicate past variation in rates of deposition and/or erosion" (RINE \& GINSBURG, 1985).

The periodicity concept of a mud - deposition - event as an exact time-scale pointing out to a cyclic sedimentation pattern is presently dismissed in fact, periodicity is controlled by a great number of interrelated factors and the goal will be to define them. On the one hand, in a recent study dealing with the accretion and erosion rates in central Suriname during 34 years (1947/1981, AUGUSTINUS et al., in press.) reveal that some areas present undoubtedly great morphological changes whereas, in other sectors, no significant variation is observed. On the other hand, our own observations suggest that during the last 30 years some coastal areas in French Guiana have either a retreating tendency (Sinnamary, Pointe Isère) or a progradation one (Iracoubo), while a few others seem relatively "stable" (P.Behague, Oyapock river mouth). Moreover, research done on sedimentary processes in the Amazon continental shelf (NITTROUER et al., 1987) shows significant variations on the present concentration and flux of suspended sediments.

There is still an enormous amount of research to be done to understand the relationships between process, sequences, periodicity and environments, particularly concerning short-term and longterm variations in the Amazon sedimenatary supply, oceanographical and climatological data, sedimentation and tectonics, etc..

\section{CONCLUSIONS}

Knowledge of present-day processes and factors is necessary to help analysis of past conditions and to predict future developments. This aim - applied in the last years in French Guiana - is now getting an increasingly regional expression. In this framework, Remote Sensing Data processing is an essential research strategy and methodology. On the one hand, exact information is supplied concerning modern coastal environment (mudflats and interbank zones extension, length, morphology and migration rates; shoreline sedimentary changes; wave action and swell diffraction in front of the coast and estuaries); on the other hand, satellite scenes processing also leads to an approach of the past development of the 
coastal area.

Concret results expected in the near future are (1) to have a better understanding of modern coastal processes and environments, (2) to produce models of sedimentary coastal change that will aid analysis and correlation with neighbouring areas, and (3) to improve strategies, methods and techniques of coastal mapping and management.

\section{ACKNOWLEDGEMENTS}

I would like to thank Marc LOINTIER (Centre ORSTOM, Cayenne) for his advice and for the fruitful discussions on Remote Sensing Data processing. I am indebted to Mrs. Bissainte for assisting with the English text.

\section{REFERENCES}

ALLERSMA, E. (1968) Mud on the oceanic shelf off Guiana. Paper CICAR Simposium Curacao. 11p.

AUGUSTINUS, P.G.E.F. (1978) The changing shoreline of Surinam (South America). Netherlands, 232p. (Thesis Doctoral - University of Utrecht).

AUGUSTINUS, P.G.E.F.; HAZELHOFF, L; KROON, A. (in press) The chenier coast of Suriname: actual and geological development.

BOUYSSE, P.H.; KUDRASS, H.R.; LE LANN, F. (1977) Reconnaissance sedimentaire du plateau continental de la Guyane Française (mission Guyamer, 1976). Bulletin du Bureau de Recherches Geologiques et Minieres. Sec. 4(2):141-180.

BOYE, M. (1959) Rapport sur l'état du dévasement du littoral de la Guyane Française et spéciallement des abords de Cayenne. ORSTOM, 1 FAT. 32p.

DELFT HYDRAULIC LAB. (1962) Demerara Coastal Investigation. Report on siltation of Demerara bar channel and coastal erosion in British Guiana. 240p.

DIEPHUIS, J.G.H.R. (1966) The Guiana coast. Tijdschr. Aardr. Gen., 83(2):145-152. 
DIEPHUIS, J.G.H.R. (1966) The Guiana coast. Tijdschr. Aardr. Gen., 83(2):145-152.

DIRECTION DEPARTAMENTALE DE L'EQUIPEMENT (1988) Historique de l'envasement du littoral de la Guyane Française. Rapport interne. Direction Departamentale de l'Equipement Cayenne. Guyane Française. 18p.

FRANZINELU, E. (1988) Evidence of Andean volcanism in recent sediments of the Amazon River. Abstract of the Chapman Conference on the fate of particulate and dissolved components within the Amazon Dispersal System: River and Ocean. Nittrouer \& DeMaster Ed. Charleston. Wild Dunes. USA. p.73-76.

FROIDEFOND, J.M. \& PROST, M.T. (1985) Etude préliminaire des déplacements du littoral de la Guyane Française par survols aériens et comparaisons cartographiques. Abstracts Colloque BORDOMER. Bordeaux. France.

FROIDEFOND, J.M.; PROST, M.T.; GRIBOULARD, R. (1985) Etude sur l'évolution morpho-sédimentaire des littoraux argileux sous climat équatorial: l'exemple du littoral guyanais. Rapport CORDET-IGBA. Univ. de Bordeaux I. Talence. 189p. Ministère de la Recherche et de la Technologie. Paris.

FROIDEFOND, J.M. \& PUJOS, M. (1988) Recognition of net deposition and erosion along the French Guiana coast based on comparison of historical maps. Abstracts Chapman Conference on the rate of particulate and dissolved components within the Amazon Dispersal System: River and Ocean. Nittrouer et DeMaster Ed. Charleston. Wild Dunes. USA. p.23.

JEANTET, D. (1982) Processus sédimentaires et évolution du plateau guyanais au cours du Quaternaire Terminal. Bordeaux, 370p. (Thèse Docteur - Université de Bordeaux).

JOUANNEAU, J.M. \& PUJOS, M. (1988) Similarities and differences in the nature and composition of estuarine sediments of French Guiana: the impact of the Amazon. Abstracts of Chapman Conference on the rate of particulate and dissolved components within the Amazon Dispersal System: River and Ocean. Nittrouer \& DeMaster Ed. Charleston. Wild Dunes. USA. p.24.

KROOK, L. (1979) Sediment petrographical studies in Northern Suriname. Amsterdam, 154p. (Thèse Academic Proefschrift Yrije Universiteit. Amsterdam. Netherlands).

KROOK, L (1988) Heavy minerals in Amazon derived sediments on the continental shelf, the Guiana coastal 
plain and the Guiana marginal plateau. Abstracts of Chapman Conference on the rate of particulate and dissolved components within the Amazon Dispersal System: River and Ocean. Nittrouer \& DeMaster Ed. Charleston. Wild Dunes. USA.

LEVEQUE, A. (1962) Mémoire explicatif de la carte de sols des Terres Basses de la Guyane Française. Mémoires. ORSTOM 3, 88p. 2 cartes 1/100.000. Paris.

LOINTIER, M. (1986) Hydrodynamique et morphologie de l'estuaire du fleuve Sinnamary (Guyane Française). In: Le littoral guyanais (fragilité de l'environnement). Nature Guyanaise: Sepanrit-Sepanguy Ed. Cayenne. Guyane Française. p.37-44.

LOINTIER, M. (1988) SPOT, les promesses d'un autre regard. Dossier in: Journal du C.N.E.S. (Centre National d'Études Spatiales) Juillet 1988, Toulouse, 52:14-15.

LOINTIER, M.T. \& PROST, M.T. (1986) Morphology and hydrology of an equatorial coastal swamp: example of the Sarcelle Swamp in French Guiana. In: RABASSA, J. (ed.). Quaternary of South America and Antarctic Peninsula. Rotterdam, A.A. Balkema. v.4, p.59-77.

LOINTIER, M. \& PROST, M.T. (1988) Coastal sedimentation and local rivers supply in French Guiana: comparisons with the Amazon. Abstracts of Chapman Conference on the rate of particulate and dissolved components within the Amazon Dispersal System: River and Ocean. Nittrouer \& DeMaster Ed. Charleston. Wild Dunes. USA. p.182-186.

LOINTIER, M. \& PROST, M.T. (1988) Environnement côtier des Guyanes. Rapport intermédiaire ORSTOM, novembre 1988. Centre ORSTOM et Conseil Régional de la Guyane, 46p., 39 figures, 7 pl., 66 ref. Cayenne, Guyane Française.

MIUMMAN, J.D. (1988) Amazon River sediment discharge to the sea: variations with time and space. Abstracts of Chapman Conference on the rate of particulate and dissolved components within the Amazon Dispersal System: River and Ocean. Nittrouer \& DeMaster Ed. Charleston. Wild Dunes. USA. p.13.

NEDECO (1968) Suriname transportation study. Report on hydraulic investigation. 239p. The Hague, Netherlands. 
NITTROUER, C.A.; CURTIN, T.B.; DEMASTER, J.T. (1987) Concentration and flux of suspended sediment on the Amazon continental shelf. Continental Shelf Research, 6(1-2):150-174.

PROST, M.T. (1986) Aspects of the morpho-sedimentary evolution of French Guiana's coastline. In: RABASSA, J.(ed.) Quaternary of South America and Antarctic Peninsula. Rotterdam, A.A. Balkema. v.4, p.191-218.

PROST, M.T. (1986) Morphologie et dynamique côtières dans la région de Mana. In: Le littoral guyanais (fragilité de l'environnement). Nature Guyanaise. Sepanguy. Sepanrit Ed. Cayenne, Guyane Française. p.31-36.

PROST, M.T. (1988) L'envasement des côtes des Guyanes. Dossier in: Journal du CNES (Centre National d'Études Spatiales), Juillet 1988. Toulouse, France. 52:15-16.

PROST, M.T. (1988) Shoreline changes in French Guiana. In: RABASSA, J. (ed.) Quaternary of South America and Antarctic Peninsula. Rotterdam, A.A. Balkema. v.5, p.291-299.

PROST, M.T. (1990) Beaches and cheniers in French Guiana. In: RABASSA, J. (ed.) Quaternary of South America and Antarctic Peninsula. Rotterdam. A.A. Balkema, 6:189-219.

PROST, M.T. (1989) Coastal dynamics and chenier sands in French Guiana. Marine Geology. Elsevier Sc. Publishers, Amsterdam. 90:259-267.

PROST, M.T. \& LOINTIER, M. (1987) Sedimentology and stratigraphy of the Holocene formations of the French Guiana's coastal plain. Publicação Avulsa. ABEQUA, 2:55-83.

PROST, M.T.; LOINTIER, M.; PANNETIER, G. (1989) L'envasement des côtes de Guyane. Revue Sepanguy. Cayenne. Guyane "Nature Guyanaise" № 1. Mars 1989. Cayenne. Guyane Française.

PUJOS, M. \& ODIN, G.S. (1986) La sédimentation au Quaternaire terminal sur la plate-forme continentale de la Guyane Française. Oceanologica Acta, 9(4):363-382.

PUJOS, M.; BOUYSSE, P.; PONS, J.C. (1988) Heavy minerals and late Quaternary palaeoenvironments of the French Guiana continental shelf. Abstracts of Chapman Conference on the rate of particulate and dissolved components within the Amazon Dispersal System: River and Ocean. Nittrouer \& DeMaster 
Ed. Charleston, Wild Dunes, USA. p.179-181.

PUJOS, M.; BOUYSSE, P.; PONS, J.C. (1988) Sources and distribution of heavy minerals in Late Quaternary environments of the French Guiana continental shelf. Continental Shelf Research, 10(1):59-79.

READING, H.G. (1986) Sedimentary environments and facies. 2.ed. Oxford, Blackwell. 615p.

RINE, J.M. (1988) Influence of the Amazon River on deposition of the Holocene coastal plain of Suriname South. Abstracts of Chapman Conference on the rate of particulate and dissolved components within the Amazon Dispersal System: River and Ocean. Nittrouer \& DeMaster Ed. Charleston. Wild Dunes. USA. p.26.

RINE, J.M. \& GINSBURG, R.N. (1985) Depositional facies of the mudshoreface in Suriname, South America a mud analogue to sandy shallow-marine deposits. Journal of Sedimentary Petrology, 55(5):633-652.

ROELEVELD, W. \& VAN LOON, A.J. (1979) The Holocene development of the young coastal plain in Suriname. Geologie en Mijnbouw, 58(4):21-28.

TISSOT, C.; DJUWANSAH, M.R.; MARIUS, C. (1987) Evolution de la mangrove en Guyane au cours de I'Holocene. Étude palynologique. Actes Xème Symposium APLF. Bordeaux. France.

TURENNE, J.F. (1978) Sédimentologie des plaines côtieres (Guyane Française). Atlas de la Guyane. CNRSORSTOM. Planche 6.

VAN DER HAMMEN, T. (1963) A palynological study on the Quaternary of British Guiana. Leidsche Geologische Mededelingen, 29:125-168.

VERSTEEG, A.H. (1985) The prehistory of the young Coastal Plain of west Suriname. Thesis. Univ. of Leiden. 652p. 102ref. Netherlands.

WIJMSTRA, T.A (1971) The palynology of the Guiana coastal basin. Netherlands. 72p. (Doctoral thesis University of Amsterdam).

WONG, E.T. (1986) Outline of the stratigraphy and the geological history of the Suriname Coastal plain. Geologie en Mijnbouw, 65(3):223-241. 